\title{
DPYD wt Allele
}

National Cancer Institute

\section{Source}

National Cancer Institute. DPYD wt Allele. NCI Thesaurus. Code C50878.

Human DPYD wild-type allele is located within $1 \mathrm{p} 22$ and is approximately $843 \mathrm{~kb}$ in length.

This allele, which encodes dihydropyrimidine dehydrogenase [NADP+] protein, plays a role in the reduction of uracil, thymine and the drug 5-fluorouracil. Hereditary defects in the DPYD gene cause an error in pyrimidine metabolism associated with both thymineuraciluria and increased toxicity of 5-fluorouracil during chemotherapy. 